\title{
Phytochemical Screening and biological potentials of Musa x paradisiaca L. leaves extract as anticancer and antioxidant agents
}

\author{
Aakash Deep ${ }^{1}$, Priya ${ }^{1}$, Om Narayan Upadhyay ${ }^{1}$, Sanjiv Kumar ${ }^{1}$, Harish Kumar ${ }^{1}$, Nitin Bansal ${ }^{1}$, Arun Kumar Sharma ${ }^{2}$, Deepak \\ Wadhwa $^{3}$ and Surender Kumar ${ }^{3}$
}

Cite this article: Deep Aakash, Priya, Upadhyay NO et al. Phytochemical Screening and biological potentials of Musa $\times$ paradisiaca $L$. leaves extract as anticancer and antioxidant agents. Asia-Pac J Pharmacother Toxicol 2021; 1: 19-27. https://doi.org/10.32948/ ajpt.2021.12.10

\begin{abstract}
Background Many of these plants, have therapeutic effects and can be extracted and used in preparation of drugs, used directly or in combination with other plant extracts for medication which is a common practice in developing counties. Unfortunately, many of those who utilize these plants therapeutically do not have adequate knowledge or training in the safe use of the products. For these reasons, natural plant products need to be standardized and preliminary studies done to evaluate possible risks such as undesirable side effects, overdose and toxicity. Results Ethyl acetate extract of Musa $\times$ paradisiaca $L$ shown anticervical carcinoma and anti-malignant melanoma activity in our study. Antioxidant activity demonstrated, that Musa $\times$ Paradisiaca L. leaves ethyl extract exhibited \% inhibition at absorbance $517 \mathrm{~nm}$ with IC50 values $=3.70$ to 45.50 at different concentration and compared with ascorbic acid as standard drug.

Conclusions The present study indicates the anticancer and antioxidant activity on the basis of biological and phytochemical screening of Musa $\times$ paradisiaca $L$ leaves extract. Ethyl acetate extract of leaves was evaluated for its anticancer activity. In vitro anticancer activity of extract were estimated by measuring significant inhibition of HeLa and A375 cell lines by MTT assay. The MTT assay clearly indicates that the inhibition or inhibitory activity of the extract was concentration dependent. Maximum inhibition of cell growth was found at the concentration of $320 \mu \mathrm{g} / \mathrm{ml}$ which was 54.35 and 55.97, respectively for HeLa and A375 cell lines. Therefore, $320 \mu \mathrm{g} / \mathrm{ml}$ concentration of extract was used to study the IC50 value that was calculated as 249.1 and 224.4, respectively. Antioxidant activity demonstrated that, plant extract exhibited percentage inhibition with IC50 values $=3.70$ to 45.50 at different concentration and compared with ascorbic acid as standard drug.
\end{abstract}

Key words Musa $\times$ paradisiaca $L$ plant, phytochemical screening, anticancer activity, antioxidant activity, MTT assay

\footnotetext{
1. Department of Pharmaceutical Sciences, Chaudhary Bansi Lal University, Bhiwani, Haryana, India.

2. Department of Pharmacology, Amity Institute of Pharmacy, Amity University, Gurugram, Haryana, India.

3. Department of Chemistry, Chaudhary Bansi Lal University, Bhiwani, Haryana, India.

Correspondence: Aakash Deep (Department of Pharmaceutical Sciences, Chaudhary Bansi Lal University, Bhiwani, Haryana, India-127021; E-mail: aakashdeep82@gmail.com).
} 


\section{Introduction}

Many medicinal plants, have therapeutic effects and can be extracted and used in preparation of drugs, used directly or in combination with other plant extracts for medication which is a common practice in developing counties. Unfortunately, many of those who utilize these plants therapeutically do not have adequate knowledge or training in the safe use of the products. For these reasons, natural plant products need to be standardized and preliminary studies done to evaluate possible risks such as undesirable side effects, overdose and toxicity [1]. The use of traditional medicines by traditional healers has played an important role in the health care of millions of people [2].

Many commercially sold medicinal plants might contain chemical substances with potential mutagenic and/or carcinogenic properties as well as with antitumor properties, and the active extracts detected by screening methods should be subjected to accurate bioassays to determine their specific pharmacological activity [3]. Cancer had always been the most serious disease in humans around the world due to its high morbidity and mortality. Cancer is among the leading causes of death worldwide. In 2018, there were 18.1 million new cases and 9.5 million cancer-related deaths worldwide. By 2040, the number of new cancer cases per year is expected to rise to 29.5 million and the number of cancerrelated deaths to 16.4 million. Cervical cancer is the third most common cancer of women after breast cancer and colorectal cancer [4]. Carcinoma cervix is a type of cancer that occurs in the cells of the cervix, the lower part of the uterus that connects it to the vagina. The incidence and mortality rate due to this cancer have declined in the developed countries over past few decades but still remains to be the most common gynecological cancer and fourth most common malignancy in women across developing countries. Death rates for female breast and cervical cancers, however, were considerably higher in transitioning versus transitioned countries (15.0 vs 12.8 per 100,000 and 12.4 vs 5.2 per 100,000, respectively) [5]. In India, it is second most common cancer in females after breast cancer, with around a lakh new cases identified annually [6]. The highest incidence was recorded in Papumpare, Aizawl, Mizoram, accounting for a total of $27 \%$ of cancer cases amongst female in India [7, 8]. It accounted for $0.3 \%$ of all cancer patients and $27 \%$ of all female cancer patients seen [8]. Infection with human papillomavirus (HPV) is associated with more than $90 \%$ cases of cervix cancer [9]. Surgery, radiotherapy or chemotherapy, alone or in combination [10], can be used as therapeutic modalities for carcinoma cervix [11]. Malignant melanoma is the most dangerous form of skin cancer [12], being fifth most common tumor type among men and sixth in women in the United States [13]. In addition, malignant melanoma is 1.4 times more common among men than in women. The incidence of both non-melanoma and melanoma skin cancers have been increasing over the past decades and are reported maximum in Australia, New Zealand, Switzerland, Denmark and Norway [14]. Ultraviolet (UV) radiation and number of moles more than 100 is the greater risk for melanoma [15].

Surgery is the definitive treatment depending on number of factors, including the type of cancer, size of the lesion, anatomic location, available resources and patient preferences for early-stage melanoma, keeping or leaving medical management generally reserved as adjuvant treatment for advanced melanoma [16]. Moreover, nowadays doctors are exploring plant extracts to treat cancer, hypothesizing their traditional use because they can be used even in palliative care as well as to reduce the side effects associated with cancer treatment. The National Cancer Institute (NCI) has collected about 35,000 plant samples from 20 countries and has screened around 114,000 extracts for anticancer activity. Over 3000 species of plants with potential antitumor activity have been reported [17]. Approximately $60 \%$ of anticancer compounds and $75 \%$ drugs for infectious disease come from natural products or their derivatives [18].

Antioxidants are the agents that neutralize free radicals, which scavenge reactive oxygen species may be high potent value in preventing the onset and propagation of oxidative diseases like neurovascular, autoimmune and cardiovascular diseases [19]. One of them is Musa $\times$ paradisiaca L. (Fig. 1) commonly known as Plantain belonging to family musaceae (banana family) [20]. It possesses several medicinal properties which include antilithiatic, antibacterial, antidiabetic, antiulcer, anti-diarrheal, hypocholesterolaemic, hepatoprotective, anti-snake venom, wound healing, hair growth promoting, anti-fungal and anti-menorrhagia activity [21].

Banana flower is a very good natural source for the development of an anticancer lead molecule with least side effects. Flower extract was checked for cytotoxicity on normal human peripheral lymphocytes. The anti-cancer activity of banana flower extract has evaluated on the cervical cancer cell line (HeLa) and displayed the highest cytotoxic activity [22]. Banana leaves acetone extract also presented vigorous activity against breast and liver hepatocellular tumor cell lines [23].

Based on aforementioned facts, we hereby report to evaluate the phytochemical screening, anticancer and antioxidant activities of Musa $\times$ paradisiaca L plant leaves extract.

\section{Materials and methods}

\section{Selection, collection and authentication of plant}

Leaves of plant Musa $\times$ paradisiaca L. were selected for the present study and were collected from Herbal Garden of Maharshi Dayanand University, Rohtak, Haryana, India in the month of February, 2018. The leaves were authenticated by Dr. Sunita Garg, Emeritus Scientist, National Institute of Science Communication and Information Resources (CSIR-NISCAIR) Delhi (Ref no.NISCAIR/RHMD/Consult/2018/3144-93).

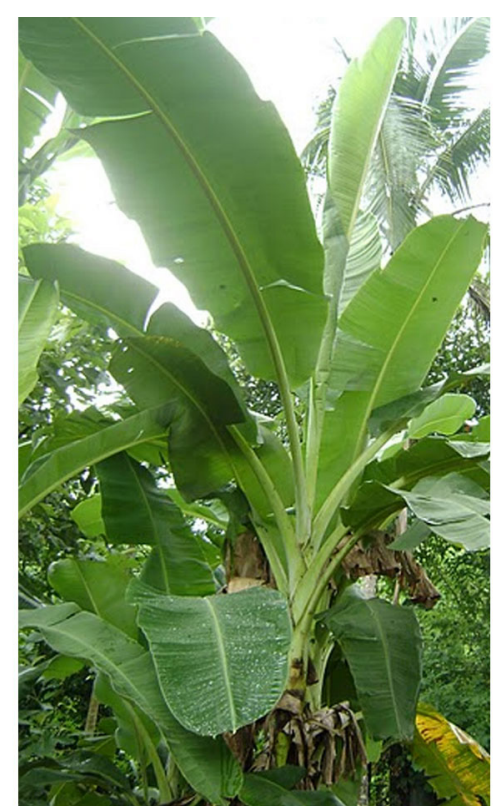

Figure 1. CONSORT 2010 Flow Diagram for the study progress. 
Table 1. Identified bioactive compounds of plant extract.

\begin{tabular}{|c|c|c|c|c|c|}
\hline Sr No. & Name of Compounds & Molecular formula & Molecular weight & Retention Time & Area\% \\
\hline 1 & 2-Ethylhexanol & $\mathrm{C}_{8} \mathrm{H}_{18} \mathrm{O}$ & 130 & 7.992 & 0.20 \\
\hline 2 & Triethyl phosphate & $\mathrm{C}_{6} \mathrm{H}_{15} \mathrm{O}_{4} \mathrm{P}$ & 182 & 10.094 & 0.19 \\
\hline 3 & Octyl acetate & $\mathrm{C}_{10} \mathrm{H}_{20} \mathrm{O}_{2}$ & 172 & 10.671 & 0.10 \\
\hline 4 & Docodecane & $\mathrm{C}_{12} \mathrm{H}_{26}$ & 170 & 11.858 & 0.26 \\
\hline 5 & Eugenol & $\mathrm{C}_{10} \mathrm{H}_{12} \mathrm{O}_{2}$ & 164 & 15.059 & 10.96 \\
\hline 6 & Copaen & $\mathrm{C}_{15} \mathrm{H}_{24}$ & 204 & 15.514 & 0.09 \\
\hline 7 & Tridecanol & $\mathrm{C}_{13} \mathrm{H}_{28} \mathrm{O}$ & 200 & 15.732 & 0.15 \\
\hline 8 & Tetradecane & $\mathrm{C}_{14} \mathrm{H}_{30}$ & 198 & 15.886 & 1.72 \\
\hline 9 & Caryophyllene & $\mathrm{C}_{15} \mathrm{H}_{24}$ & 204 & 16.372 & 1.40 \\
\hline 10 & Alpha caryophyllene & $\mathrm{C}_{15} \mathrm{H}_{24}$ & 204 & 17.032 & 0.20 \\
\hline 11 & Acetyl eugenol & $\mathrm{C}_{12} \mathrm{H}_{14} \mathrm{O}_{3}$ & 164 & 17.979 & 1.93 \\
\hline 12 & $\beta$-Cadinene & $\mathrm{C}_{15} \mathrm{H}_{24}$ & 204 & 18.118 & 0.18 \\
\hline 13 & Octadecane & $\mathrm{C}_{18} \mathrm{H}_{38}$ & 254 & 18.937 & 0.26 \\
\hline 14 & Acetic acid, chloro- hexadecyl ester & $\mathrm{C}_{18} \mathrm{H}_{35} \mathrm{ClO}_{2}$ & 318 & 19.303 & 0.59 \\
\hline 15 & Henicosane & $\mathrm{C}_{21} \mathrm{H}_{44}$ & 296 & 21.857 & 0.21 \\
\hline 16 & Hexadecyl iodide & $\mathrm{C}_{16} \mathrm{H}_{33} \mathrm{I}$ & 352 & 22.176 & 0.43 \\
\hline 17 & 1-Nonadecene & $\mathrm{C}_{19} \mathrm{H}_{38}$ & 266 & 22.515 & 0.32 \\
\hline 18 & Phytane & $\mathrm{C}_{20} \mathrm{H}_{42}$ & 282 & 22.623 & 2.68 \\
\hline 19 & Cyclohexane, 1-butylnonyl & $\mathrm{C}_{18} \mathrm{H}_{36}$ & 252 & 22.786 & 0.30 \\
\hline 20 & Neophytadiene & $\mathrm{C}_{20} \mathrm{H}_{38}$ & 278 & 23.166 & 1.32 \\
\hline 21 & Perhydrofarnesyl acetone & $\mathrm{C}_{18} \mathrm{H}_{36} \mathrm{O}$ & 268 & 23.242 & 0.30 \\
\hline 22 & Phytol, acetate & $\mathrm{C}_{22} \mathrm{H}_{42} \mathrm{O}_{2}$ & 338 & 23.521 & 0.39 \\
\hline 23 & Tetracontane & $\mathrm{C}_{40} \mathrm{H}_{82}$ & 562 & 24.709 & 0.33 \\
\hline 24 & Octacosane & $\mathrm{C}_{28} \mathrm{H}_{58}$ & 394 & 24.810 & 0.20 \\
\hline 25 & Dibutyl phthalate & $\mathrm{C}_{16} \mathrm{H}_{22} \mathrm{O}_{4}$ & 278 & 24.892 & 5.08 \\
\hline 26 & Hexadecanoic acid & $\mathrm{C}_{16} \mathrm{H}_{32} \mathrm{O}_{2}$ & 256 & 25.033 & 1.58 \\
\hline 27 & Tetracosane, 1-iodo- & $\mathrm{C}_{24} \mathrm{H}_{49} \mathrm{I}$ & 464 & 25.110 & 0.41 \\
\hline 28 & Heptacosanol & $\mathrm{C}_{27} \mathrm{H}_{56} \mathrm{O}$ & 396 & 25.418 & 0.33 \\
\hline 29 & Tetracosane & $\mathrm{C}_{24} \mathrm{H}_{50}$ & 338 & 25.509 & 2.00 \\
\hline 30 & Undecane, 4-cyclohexyl & $\mathrm{C}_{17} \mathrm{H}_{34}$ & 238 & 25.731 & 0.22 \\
\hline 31 & Heptacosano & $\mathrm{C}_{27} \mathrm{H}_{56} \mathrm{O}$ & 296 & 26.709 & 0.84 \\
\hline 32 & Tetracontane & $\mathrm{C}_{40} \mathrm{H}_{82}$ & 562 & 26.855 & 0.59 \\
\hline 33 & Phytol & $\mathrm{C}_{20} \mathrm{H}_{40} \mathrm{O}$ & 296 & 27.019 & 5.43 \\
\hline 34 & Pentatriacontane & $\mathrm{C}_{35} \mathrm{H}_{72}$ & 492 & 27.345 & 0.32 \\
\hline 35 & Phytol, acetate & $\mathrm{C}_{22} \mathrm{H}_{42} \mathrm{O}_{2}$ & 338 & 27.491 & 0.55 \\
\hline 36 & 3-Methyloctadecane & $\mathrm{C}_{19} \mathrm{H}_{40}$ & 268 & 27.786 & 0.34 \\
\hline 37 & Palmitic acid, butyl ester & $\mathrm{C}_{20} \mathrm{H}_{40} \mathrm{O}_{2}$ & 312 & 27.953 & 3.80 \\
\hline 38 & Docosane & $\mathrm{C}_{22} \mathrm{H}_{46}$ & 310 & 28.147 & 1.71 \\
\hline 39 & Tetratriacontylheptafluorobutyrate & $\mathrm{C}_{38} \mathrm{H}_{69} \mathrm{~F}_{7} \mathrm{O}$ & 690 & 28.237 & 0.31 \\
\hline 40 & Phytylpalmitate & $\mathrm{C}_{36} \mathrm{H}_{70} \mathrm{O}_{2}$ & - & 28.296 & 0.30 \\
\hline
\end{tabular}




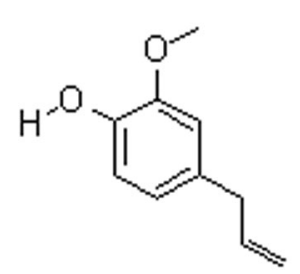

A<smiles>C/C(=C\CO)CCCC(C)CCCC(C)CCCC(C)C</smiles>

B

Figure 2. Structure of Eugenol (A) and Phytol (B).

\section{Drying and powdering of plant material}

The fresh leaves of Musa $\times$ paradisiaca L. were selected and washed under running and chopped into fine pieces and air dried in shade for 15 days. The dried leaves were crushed into coarse powder.

\section{Preparation of extract}

The coarse powder was extracted using Soxhlet apparatus [24]. The powder of dried leaves was defatted with petroleum ether for 6 $h$. The treated powder was further processed with ethyl acetate for $18 \mathrm{~h}$ and then it was concentrated by evaporating the solvent using water bath maintained at $60-80^{\circ} \mathrm{C}$.

Qualitative analysis of extract by Gas Chromatography-Mass Spectrometry (GC-MS)

GC-MS Analysis of extract was carried out on a GC7890 (Agilent) comprising automatic liquid sampler and gas chromatograph interfaced to mass spectrophotometer (GC-MS) at Jawaharlal Nehru University, New Delhi, using Helium as a carrier and the injector temperature $270{ }^{\circ} \mathrm{C}$. The oven temperature was programmed from $60^{\circ} \mathrm{C}$ held for $15 \mathrm{~min}$ to $280^{\circ} \mathrm{C}$ at $15^{\circ} \mathrm{C} / \mathrm{min}$.

\section{Antioxidant evaluation}

The antioxidant activity of ethyl acetate extract of Musa $\times$ paradisiaca L. leaf and standard ascorbic acid was evaluated on the basis of the radical scavenging effect of the stable 1, 1-diphenyl2-picrylhydrazyl (DPPH) free radical activity by modified DPPH assay [25]. DPPH $0.1 \mathrm{mM}$ in methyl alcohol was prepared and 0.5 $\mathrm{ml}$ of this solution was added to $1 \mathrm{ml}$ of banana leaves extracts at different concentrations i.e. 5, 10, 20, and $40 \mu \mathrm{g} / \mathrm{ml}$. Methanol was used as a blank control and allowed to stand at room temperature for $30 \mathrm{~min}$. Ascorbic acid was used as a positive control and negative control contained the entire reaction reagent except for the extracts. In this test, DPPH act as free radical scavenger as it accepts hydrogen $(\mathrm{H})$ from the scavenging molecule and changes color from purple to yellow. The absorbance of the sample was measured by UV spectroscopy at $517 \mathrm{~nm}$ [26]. The inhibition was calculated as \% inhibition. The concentration of extract was taken on $\mathrm{X}$-axis whereas percentage of inhibition was taken on Y-axis for plotting the graph. DPPH assay clearly indicate that extract was effective in scavenging of free radical with compare of ascorbic acid. The inhibition activity was concentration dependent and with the increase in the concentration of extract shows more efficiency in inhibition. The absorbance was noted and $\%$ inhibition was calculated as follows:

$\%$ Inhibition $=[($ Abs standard - Abs sample $) /$ Abs standard $\mathrm{x} 100]$ Absorbance (Abs)

\section{Evaluation of extract by MTT assay}

\section{Preparation of test solutions}

Preparation of stock solutions $(32 \mathrm{mg} / \mathrm{ml})$ of the test sample in methanol for anticancer activity and serially three-fold dilutions were prepared from $10,20,40,80,160$, and $320 \mu \mathrm{g} / \mathrm{ml}$ using

Table 2. Antioxidant activity of ethyl acetate extract of Musa x paradisiaca L. leaves.

\begin{tabular}{|c|c|c|c|c|}
\hline S. No. & $\begin{array}{l}\text { Concentration }(\mu \mathrm{g} / \\
\mathrm{ml})\end{array}$ & Absorbance at $517 \mathrm{~nm}$ & $\%$ inhibition of extract & $\begin{array}{l}\text { \%inhibition of } \\
\text { Ascorbic acid }\end{array}$ \\
\hline 1. & 5 & 0.622 & $3.70 \pm 0.75$ & $6.70 \pm 0.23$ \\
\hline 2. & 10 & 0.527 & $16.94 \pm 0.65$ & $14.00 \pm 0.76$ \\
\hline 3. & 20 & 0.240 & $30.28 \pm 1.23$ & $40.50 \pm 1.43$ \\
\hline 4. & 40 & 0.057 & $45.50 \pm 2.43$ & $55.32 \pm 2.64$ \\
\hline
\end{tabular}

Values are mean $\pm \mathrm{SD}$ of 3 replicates. 


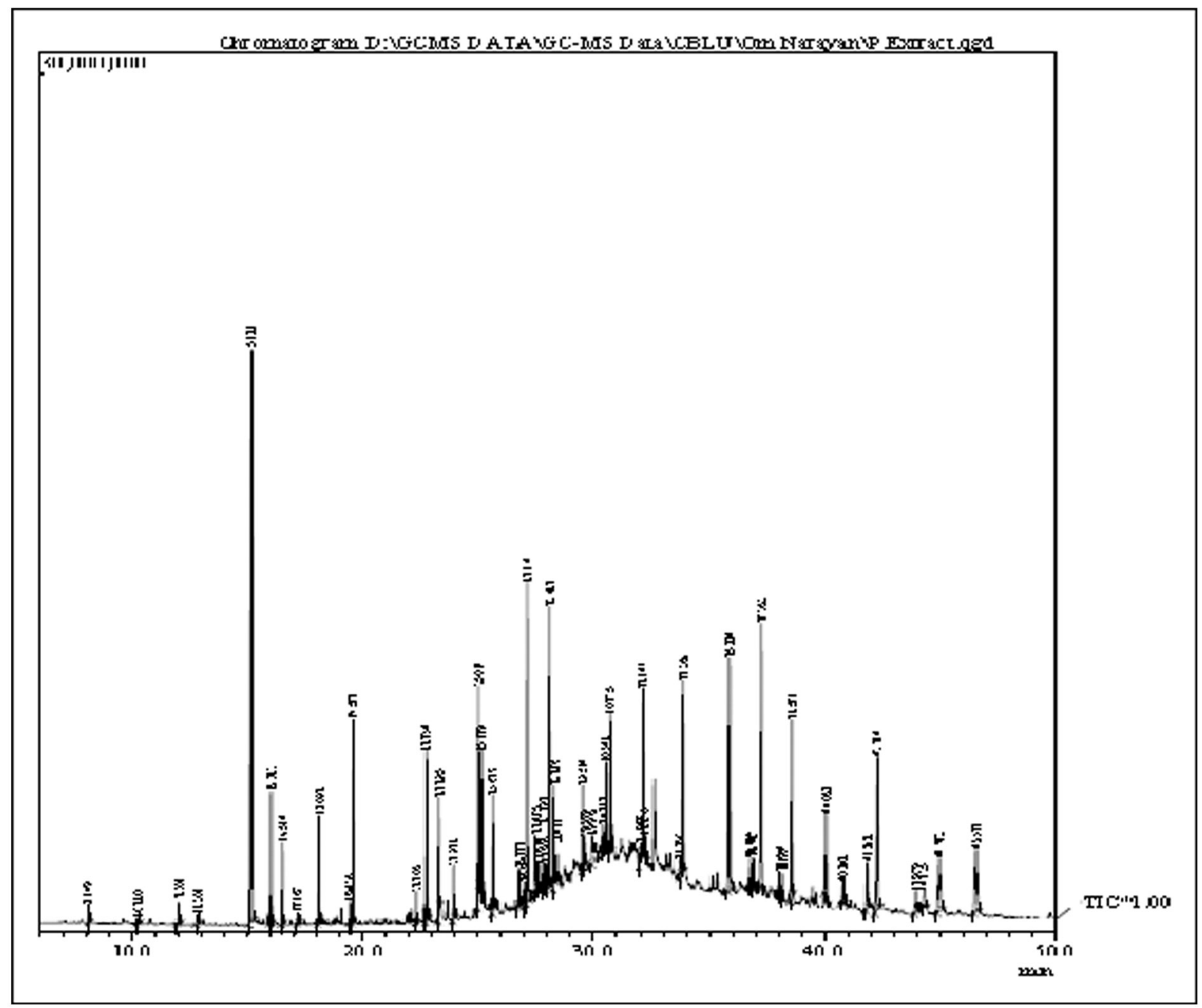

Figure 3. Chromatogram of GC-MS from ethyl acetate extract of Musa $\times$ paradisiaca $L$.

DMEM plain media for treatment.

Cell lines and culture medium

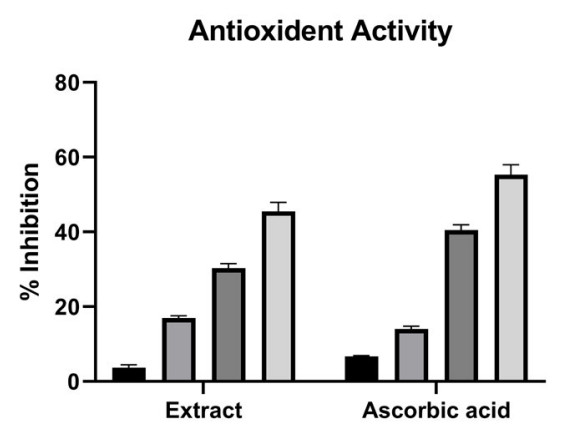

Figure 4. Graphical representation of antioxidant activity $(\%$ inhibition) $(\mathbf{n} \pm$ SD) $n=3$.

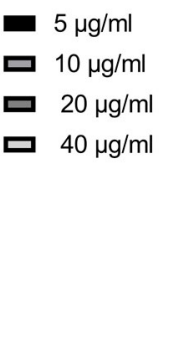

All the cell lines were procured from ATCC. Stock cells were

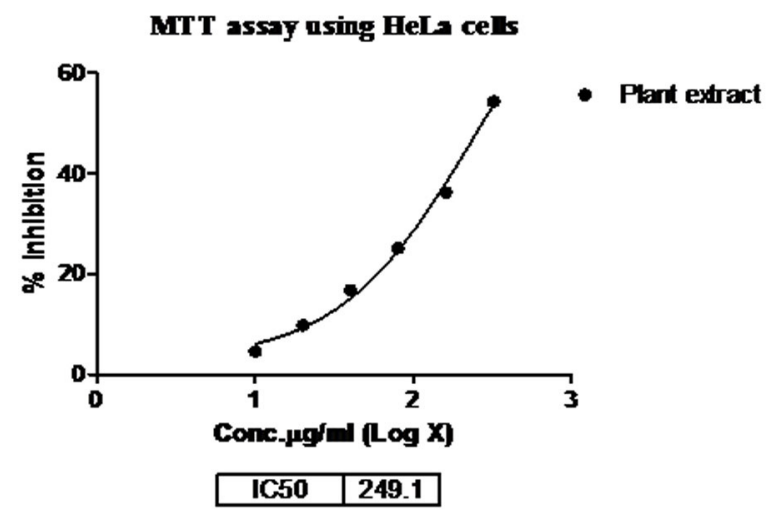

Figure 5. Dose response curve of extract against HeLa cancer cell lines $(\mathrm{n} \pm \mathrm{SD}) \mathrm{n}=\mathbf{3}$. 

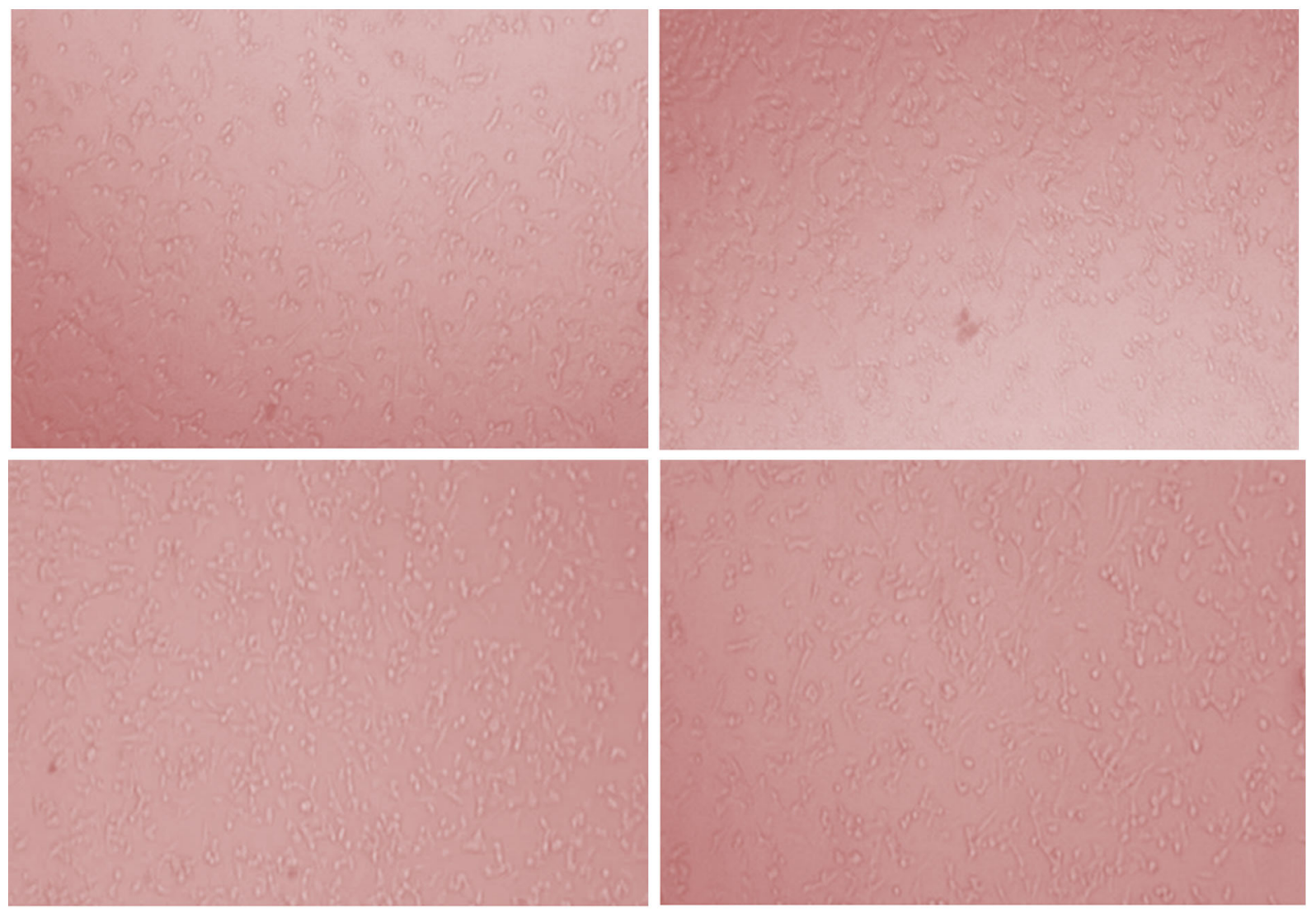

Figure 6. Growth inhibition against HeLa cancer cell line.

cultured in DMEM, supplemented with $10 \%$ inactivated Fetal Bovine Serum (FBS), penicillin (100 IU/ml), streptomycin (100 $\mu \mathrm{g} / \mathrm{ml})$ in a humidified atmosphere of $5 \% \mathrm{CO} 2$ at 37 oC until confluent. The cells were dissociated with cell dissociating solution ( $0.2 \%$ trypsin, $0.02 \%$ EDTA, $0.05 \%$ glucose in PBS). The viability of the cells was checked and centrifuged. Further, 50,000 cells per well were seeded in a 96 well plate and incubated for $24 \mathrm{~h}$ at $37 \mathrm{oC}$, in $5 \% \mathrm{CO} 2$ incubator or with $5 \% \mathrm{CO} 2$ atmosphere.

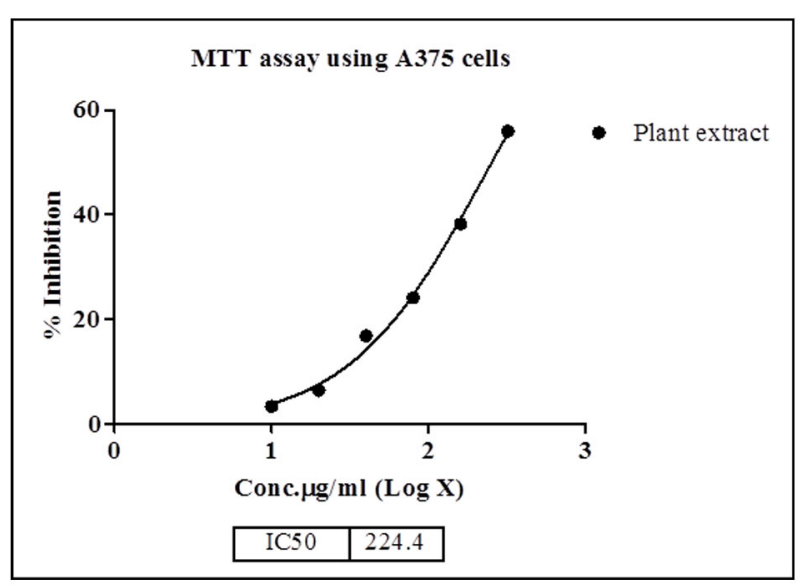

Figure 7. Dose response curve of extract against A375 cell lines $(\mathbf{n} \pm$ SD). $\mathbf{n}=\mathbf{3}$.

\section{Procedure}

The monolayer cell culture was trypsinized and the cell count was adjusted to

$1.0 \times 105$ cells $/ \mathrm{ml}$ using respective media containing $10 \%$ FBS. To each well of the 96 well microtiter plate, $100 \mu$ of the diluted cell suspension $(50,000$ cells/well) was added. The extract was tested at six different concentrations in triplet form i.e. 10, 20, 40, 80,160 , and $320 \mu \mathrm{g} / \mathrm{ml}$. After $24 \mathrm{~h}$, when a partial monolayer was formed, the supernatant was flicked off, washed the monolayer once with medium and $100 \mu \mathrm{l}$ of different test concentrations of test drugs were added on to the partial monolayer in microtiter plates. The plates were then incubated at $37 \mathrm{oC}$ for $24 \mathrm{~h}$ in $5 \% \mathrm{CO} 2$ atmosphere. After incubation, the test solutions in the wells were discarded and $100 \mu \mathrm{l}$ of MTT (6 mg/10 ml of MTT in PBS) was added to each well. The plates were incubated for $4 \mathrm{~h}$ at $37 \mathrm{oC}$ in $5 \%$ CO2 atmosphere. The supernatant was removed and $100 \mu 1$ of dimethyl sulphoxide (DMSO) was added and the plates were gently shaken to solubilize the formed formazan. The absorbance was measured using a microplate reader at a wavelength of 590 $\mathrm{nm}$. The percentage growth inhibition was calculated using the following formula and concentration of test drug needed to inhibit cell growth by $50 \%$ (IC50) value is generated from the doseresponse curves for each cell line [27-29].

$\%$ Inhibition $=100-(\mathrm{OD}$ of sample $/ \mathrm{OD}$ of

Control) x 100

where OD is the optical density. 

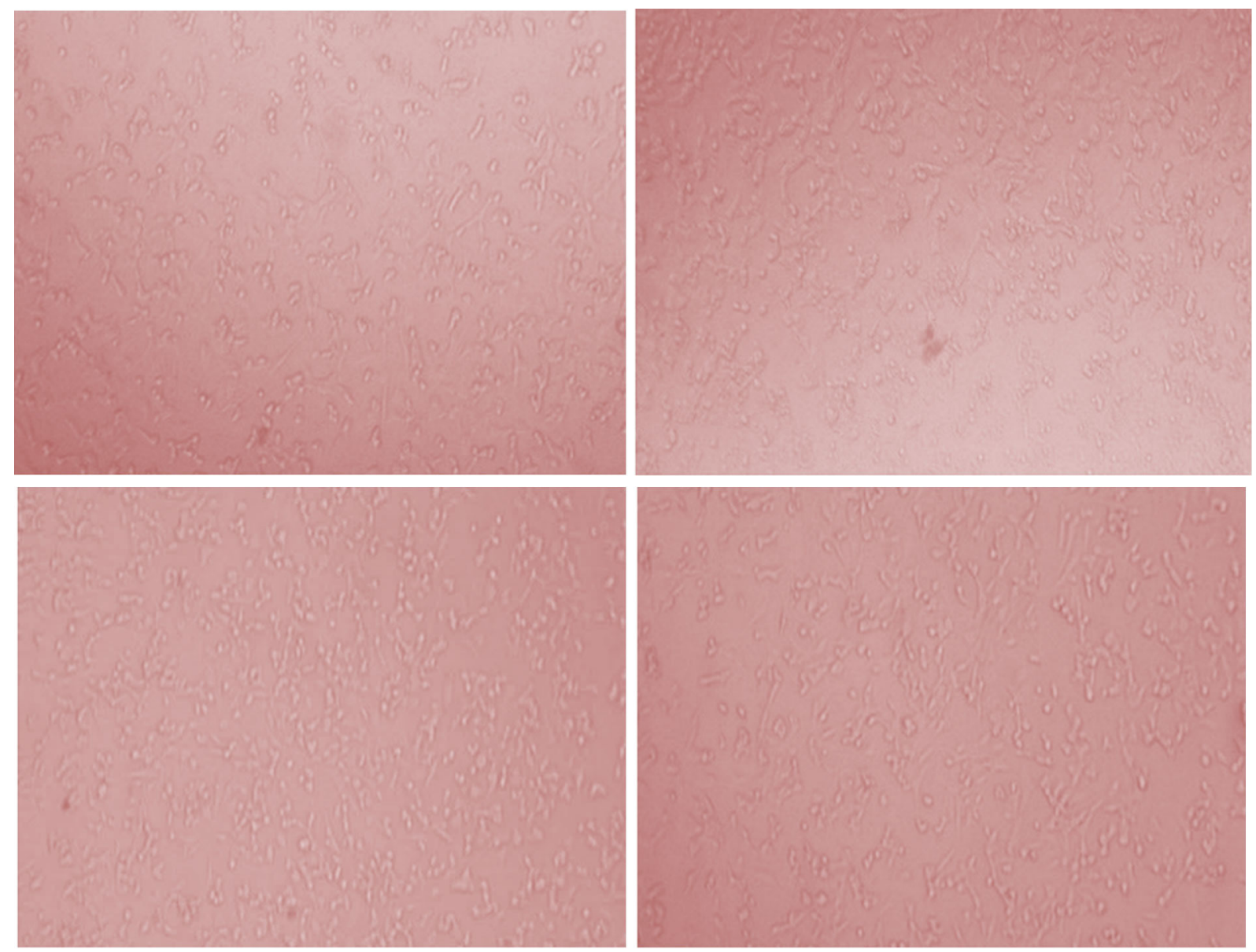

Figure 8. Growth inhibition against A375 cell line.

Statistical analysis

IC50 Values were derived from a nonlinear regression analysis (curve fit) based on sigmoid dose response curve (variable) and computed using Graph Pad Prism 6 (Graph pad, San Diego, CA, USA).

\section{Results and discussion}

Table 3. Anticancer screening results of plant leave extract on HeLa cell line.

\begin{tabular}{|c|c|c|c|c|}
\hline \multirow{2}{*}{ Cancer cell (HeLa) } & \multicolumn{4}{|c|}{ Anticancer screening results - MTT assay } \\
\hline & Conc. $(\mu \mathrm{g} / \mathrm{ml})$ & OD at $590 \mathrm{~nm}$ & $\%$ Inhibition & $\mathrm{IC}_{50}(\mu \mathrm{g} / \mathrm{ml})$ \\
\hline \multirow[t]{4}{*}{ Control } & 0 & $0.582 \pm 0.02$ & 0.00 & - \\
\hline & 10 & $0.555 \pm 0.01$ & 4.56 & \\
\hline & 20 & $0.525 \pm 0.01$ & 9.77 & \\
\hline & 40 & $0.484 \pm 0.04$ & 16.75 & \\
\hline \multirow[t]{4}{*}{ Leave extract } & & & & 249.1 \\
\hline & 80 & $0.435 \pm 0.02$ & 25.19 & \\
\hline & 160 & $0.371 \pm 0.03$ & 36.20 & \\
\hline & 320 & $0.265 \pm 0.01$ & 54.35 & \\
\hline
\end{tabular}

Experimental results are expressed as mean $\pm \mathrm{SD}$. All measurements were replicated three times. The data were analyzed by an analysis of variance $(\mathrm{P}<0.05)$. 
Table 4. Anticancer screening results of plant leave extract on A375 cell line.

\begin{tabular}{|c|c|c|c|c|}
\hline \multirow{2}{*}{$\begin{array}{c}\text { Cancer cell } \\
\text { (A375) }\end{array}$} & \multicolumn{4}{|c|}{ Anticancer screening results - MTT assay } \\
\hline & Conc. $(\mu \mathrm{g} / \mathrm{ml})$ & OD at $590 \mathrm{~nm}$ & $\%$ Inhibition & $\mathrm{IC}_{50}(\mu \mathrm{g} / \mathrm{ml})$ \\
\hline Control & 0 & $0.681 \pm 0.04$ & 0.00 & - \\
\hline \multirow{7}{*}{ Leave extract } & 10 & $0.659 \pm 0.02$ & 3.32 & \multirow{7}{*}{224.4} \\
\hline & 20 & $0.638 \pm 0.006$ & 6.43 & \\
\hline & 40 & $0.567 \pm 0.03$ & 16.82 & \\
\hline & & & & \\
\hline & 80 & $0.517 \pm 0.02$ & 24.11 & \\
\hline & 160 & $0.421 \pm 0.04$ & 38.20 & \\
\hline & 320 & $0.300 \pm 0.01$ & 55.97 & \\
\hline
\end{tabular}

Experimental results are expressed as mean \pm SD. All measurements were replicated three times. The data were analyzed by an analysis of variance $(\mathrm{P}<0.05)$.

\section{Qualitative analysis of extract by $G C-M S$}

Banana flower is a very good natural source for the development of an anticancer lead molecule with least side effects. Flower extract was checked for cytotoxicity on normal human peripheral lymphocytes. The anti-cancer activity of banana flower extract has evaluated on the cervical cancer cell line (HeLa CCL2) and displayed the highest cytotoxic activity [22]. Forty bioactive compounds were identified in qualitative analysis by Gas Chromatography-Mass spectrometry (GC-MS) from ethyl acetate extract of Musa $\times$ paradisiaca $L$. The name of compound, molecular formula, molecular weight, retention time and percentage of the identified component were ascertained (Table 1). The nine major compounds having highest peak in chromatogram was eugenol (10.96\% of area), phytol (5.43\% of area), dibutyl phthalate $(5.08 \%$ of area), palmitic acid (3.80\% of area), phytane ( $2.68 \%$ of area), tetradocosone $(2.0 \%$ of area), tetradecane $(1.72$ $\%$ of area), docosane (1.71\% of area), hexadeccanoic acid (1.58 $\%$ of area) and caryophyllene (1.40\% of area). Other compounds identified were acetyl eugenol, neophytadine, docodecane and heptacosano. Phytol and Eugenol shows higher antioxidant and anticancer activity. The chemical structure and GCMS graph of Eugenol and Phytol are shown in Fig. 2 and 3, respectively. Although much remains to be learned in each of anticancer and antioxidant research area that no doubt will have an impact on the management of cancer, it is already possible to identify new directions in cancer and oxidant treatment. The approaches that are being pursued at present study are essentially for (a) the development of specific or highly selective anticancer agents (b) the leaves extract show the significant inhibition on cancer cell line (c) the plant extract also show the antioxidant results with \% inhibition at absorbance $517 \mathrm{~nm}$.

\section{Antioxidant screening results}

Antioxidant activity demonstrated, that Musa $\times$ Paradisiaca L leaves ethyl extract exhibited \% inhibition at absorbance $517 \mathrm{~nm}$ with IC50 values $=3.70$ to 45.50 at different concentration and compared with ascorbic acid as standard drug. At the concentration of $10 \mu \mathrm{g} / \mathrm{ml}$, extract showed the better activity as compared to the standard drug. The presented results are showing in Fig. 4 and Table 2.
Anticancer screening results

Musa $\times$ Paradisiaca L. leaves ethyl extract was tested for the evaluation of status of anticancer screening by MTT assay against HeLa and A375 cancer cell lines. The extract was tested at six different concentrations in triplet form i.e. 10, 20, 40, 80, 160 and $320 \mu \mathrm{g} / \mathrm{ml}$. The MTT assay indicates that the inhibition activity of the extract was dependents on the concentration of the plant extract because increases the concentration of extract shows the more efficiency in inhibition. Maximum inhibition of cell growth was found at concentration $320 \mu \mathrm{g} / \mathrm{ml}$ (54.35\% inhibition and 55.97\% inhibition, respectively for $\mathrm{HeLa}$ and A375 cancer cell line). Therefore, $320 \mu \mathrm{g} / \mathrm{ml}$ concentration of extract was used to study the IC50 value that was calculated as 249.1 and 224.4, respectively. The presented results (IC50 value) are showing in Table 3, Figs. 5, 6 (for HeLa cancer cell) and Table 4, Figs. 7, 8 (for A375 cancer cell).

Out of various GC-MS constituents of Musa $\times$ paradisiaca L leaves extract, Phytol and Eugenol shows higher antioxidant and anticancer activity [30-31].

\section{Conclusion}

The biological and phytochemical screening of Musa $\times$ paradisiaca $\mathrm{L}$ leaves extract indicated its anticancer and antioxidant potential. Ethyl acetate extract of leaves was evaluated for its anticancer activity. In vitro anticancer activity of extract showed significant inhibition of HeLa and A375 cancer cell lines, when evaluated by MTT assay. The MTT assay clearly indicates that the inhibition or inhibitory activity of the extract was concentration dependent. Maximum inhibition of cell growth was found at the concentration of $320 \mu \mathrm{g} / \mathrm{ml}$ which was $54.35 \%$ inhibition and $55.97 \%$ inhibition for Hela and A375 cell lines and IC50 value was 249.1 and 224.4 respectively. Antioxidant activity demonstrated, plant extract exhibited percentage inhibition with IC50 values $=3.70$ to 45.50 at different concentration and compared with ascorbic acid as standard drug. Various GC-MS constituets of Musa $\times$ paradisiaca L leaves extract shows great antioxidant and anticancer activity, these are Eugenol, tetradecane, caryophyllene, alpha caryophyllene, acetyl euggenol, octyl acetate, neophytadiene, phytol, palmitic 
acid, and phytyl palmitate. Out of these constituents Phytol and Eugenol shows higher antioxidant and anticancer activity.

\section{Ethics approval and consent to participate}

None.

\section{Funding}

Not applicable.

\section{Author contributions}

Aakash Deep, Om Narayan Upadhyay, Priya, Sanjiv Kumardesigned and performed the experimental work; Arun Kumar Sharma- performed anticancer activity; Nitin Bansal and Harish Kumar performed the characterization of data and Surender Kumar, Deepak Wadhwa- designed the final manuscript.

\section{Competing interests}

All authors disclose no competing interests.

\section{References}

1. Ala AA, Olotu BB, Ohia CMD. Assessment of cytotoxicity of leaf extracts of Andrographis paniculata and Aspilia africana on murine cells in vitro. Arch Basic Appl Med 2008; 6(1): 61-65.

2. Lombardi VRM, Carrera I, Cacabelos R. In vitro screening for cytotoxic activity of herbal extracts. Evid.-Based complementary Altern Med 2017; 1-8.

3. Sigidi MT, Anokwuru CP, Zininga T, Tshisikhawe MP, Shonhai A, Ramaite IDI, Traoré AN, Potgieter N. Comparative in vitro cytotoxic, anti-inflammatory and anti-microbiological activities of two indigenous Venda medicinal plants. J Transl Medi 2016; 1(9): $1-7$.

4. Liang $\mathrm{C}$, Pan $\mathrm{H}, \mathrm{Li} \mathrm{H}$, Zhao Y, Feng Y. In vitro anticancer activity and cytotoxicity screening of phytochemical extracts from selected traditional Chinese medicinal plants. JBUON 2017; 22(2): 543-551.

5. Torre LA, Bray F, Siegel RL, Ferlay J, Lortet-Tieulent J, Jemal A Global cancer statistics, 2012. CA: A Cancer J Clin 2012; 65: 87-108.

6. Ferlay J, Soeriomataram I, Ervik M, Dikshit R, Esre R, Mathers C GLOBOCON 2012 v1.0, Cancer Incidance and Mortality Worldwide: IARC Cancer Base No 11 [INTERNET]. Lyon, France, IARC 2013.

7. National Cancer Registry Programme (NCRP, ICMR). Comparison of Cancer incidence and patterns of all population based cancer registries Banglore: NCRP: 2012-2014.

8. State wise distribution of cancer: Data for the year 2015, Retrieved I January 2016 from Radioth.erapy OPD Record Section, Pt.B. D. Sharma PGIMS, Rohtak.

9. Halperin EC, Brady LW, Wazer DE, Perez CA. Perez \& Brady's principles and practice of radiation oncology. Lippincott Williams \& Wilkins 2013; 2013: 1335-1425.

10. Marchiole P, Benchaib M, Buenerd A, Lazlo E, Dargent D, Mathevet P. Oncological safety of laparoscopic-assisted vaginal radical trachelectomy (LARVT or Dargent's operation): a comparative study with laparoscopic-assisted vaginal radical hysterectomy (LARVH). Gynecologic Oncology 2007; 106: 132-141.

11. Ostör AG. Studies on 200 cases of early squamous cell carcinoma of the cervix. Int J Gynecol Patho 1993; 12: 193-207.

12. Anand S, Verma R, Vaja C, Bade R, Shah A, Gaikwad K. Metastatic malignant melanoma: A case study. Int J Sci Study 2016; 4: 188-190.

13. Aim at melanoma; https://www.aimatmelanoma.org/aboutmelanoma/melanoma-stats-facts-and-figures/2018.

14. Erdmann F, Lortet-Tieulent J, Schüz J, Zeeb H, Greinert R, Breitbart $\mathrm{EW}$, Bray F. International trends in the incidence of malignant melanoma 1953-2008 - are recent generations at higher or lower risk? Int J Cancer 2013; 132: 385-400.

15. Health effect of UV radiation, World Health Organization 2018. Available on www.int/uv/healthuv_health $2 /$ en/index/html

16. Winston W. Malignant Melanoma Clinical Presentation. https:// emedicine. medscape.com/article/280245-clinical; 2018.

17. Chanda S, Nagani K. In vitro and in vivo methods for anticancer activity evaluation and some Indian medicinal plants possessing anticancer properties: an overviewn. Int J Pharmacogn Phytochem 2013; 2(2): 140-152

18. Reddy AR, Grace JR. Anticancer activity of methanolic extracts of selected mangrove plants. Int J Pharm Sci Res 2016; 7(9): 3852-3856.

19. Rani J, Saini M, Kumar S, Verma PK. Design, synthesis and biological potentials of novel tetrahydroimidazo[1,2-a]pyrimidine derivatives (2017) Chemistry Central Journal 2017; 11(16): 1-11.

20. Hussain A, Khan MN, Sajid MS, Iqbal Z, Khan MK, Abbas RZ, Raza MA, Needham GR. In vitro screening of the leaves of Musa paradisiaca for antihelmintic activity. J Animal Plant Sci 2010; 20: 5-8.

21. Lavanya K, Beaulah A, Vani G. Musa paradisiaca-A review on photochemistry and pharmacology. World J Pharma Med Res 2016; 2(6): 163-173.

22. Timsina B, Nadumane VK. Anti-cancer potential of banana flower extract: An in-vitro study. Bangladesh J Pharmacol 2014; 9: 628-635.

23. Salama ZA, Aboul-Enein AM, Gaafar AA, Asker MS, Aly HF, Ahmed HA. In-vitro antioxidant, antimicrobial and anticancer activities of banana leaves (Musa acuminata) and Olive leaves (Olea europaea L.) as by-products. Research J Pharm Tech 2020; 13(2): 687-696.

24. Azwanida, NN. A review on the extraction methods use in medicinal plants, principle, strength and limitation. Med Aromat Plants 2015; 4: 3-8.

25. Faujdar S, Nain S, Kalia AN. Antioxidant activity and estimation of total phenolic content of Momordica balsamina. Int J Adv Res 2013; 2(2): 233-238.

26. Mishra K, Ojha H, Chaudhury NK (2012) Estimation of antiradical properties of antioxidants using DPPH assay: A critical review and results. Food Chem 2012; 130: 1036-1043.

27. Galocha-León C, Clares-Naveros B, Gálvez-Martín P. Main analytical methods for the viability assessment of mesenchymal stem cells for use as cellular medicines. Curr Pharm Anal 2018; 14: 427436.

28. Denizot F, Lang R. Rapid colorimetric assay for cell growth and survival: modifications to the tetrazolium dye procedure giving improved sensitivity and reliability. J Imuno Methods 1986; 89: 271277.

29. Mosmann T. Rapid colorimetric assay for cellular growth and survival: application to proliferation and cytotoxicity assays. J Immunol Met 1983; 65: 55-63.

30. Alencar M.VOB, Islam M.T, Ali E.S, Santos J.V.O, Paz M.FCJ, Sousa J.MC, Dantas S.MMM, Mishra S.K, Cavalcante A.ACM. Association of Phytol with Toxic and Cytotoxic Activities in an Antitumoral Perspective: A Meta-Analysis and Systemic Review. Anti-Cancer Agents in Medicinal Chemistry 2018; 18(13).

31. Bezerra D.P, Militai G.C.G, De Morais M.C, and De Sousa P, The dual Antioxidant/Pooxidant effect of Eugenol and its action in cancer development and treatment. Nutrients 2017; 9(12): 1367. 